HISTORIA: Jurnal Pendidik dan Peneliti Sejarah, 4(2), 103-114. DOI: https://doi.org/10.17509/historia.v4i2.25740

Available online at HISTORIA; Jurnal Pendidik dan Peneliti Sejarah
Journal homepage: https://ejournal.upi.edu/index.php/historia

\title{
PERANCANGAN APLIKASI VIRTUAL REALITY CAGAR BUDAYA UNTUK PEMBELAJARAN SEJARAH LOKAL
}

\author{
Shela Dwi Utari ${ }^{1}$, Maya Luthfia Agustin ${ }^{1}$, Adam Maulana Dzikri ${ }^{2}$, Lutfiah Ayundasari ${ }^{1}$ \\ ${ }^{1} J u r u s a n$ Pendidikan Sejarah, Universitas Negeri Malang \\ ${ }^{2} J u r u s a n$ Pendidikan Teknik Informatika, Universitas Negeri Malang \\ sheladwi.utari15@gmail.com
}

To cite this article: Utari, S.D., Agustin, M.L., Dzikri, A.M, \& Ayundasari, L. (2021). Perancangan aplikasi virtual reality cagar budaya untuk pembelajaran sejarah lokal. HISTORIA: Jurnal Pendidik dan Peneliti Sejarah, 4(2), 103-114. https://doi. org/10.17509/historia.v4i2.25740.

Naskah diterima : 24 Juni 2020, Naskah direvisi : 19 Mei 2021, Naskah disetujui : 7 Juni 2021

\begin{abstract}
This study contains a study of the role of virtual reality in learning local history in history learning. The focus of this research is to develop a cultural heritage virtual reality learning media in Pasuruan. The research method used in this article is RAD (Rapid Application Development), including requirements planning (preparation), design and testing, and implementation (implementation stage). The results showed that using learning media on a virtual reality basis can present a real object of cultural heritage in Pasuruan. Learning local history using this virtual reality application provides a better understanding of cultural heritage in Pasuruan. Virtual reality pasuruan cultural heritage can make students and teachers do not have to come directly to the location and facilitate the learning process more contextual.
\end{abstract}

Keywords: Cultural heritage; Local History Learning; Virtual reality.

\begin{abstract}
Abstrak
Penelitian ini memuat kajian mengenai peranan virtual reality dalam proses pembelajaran sejarah lokal pada pembelajaran sejarah. Fokus dari penelitian ini adalah untuk mengembangkan media pembelajaran virtual reality cagar budaya di Pasuruan. Metode penelitian yang digunakan dalam artikel ini yaitu RAD (Rapid Application Development) meliputi requirements plannning (persiapan), design and testing, dan implementation (tahap pelaksanaan). Hasil penelitian menunjukkan bahwa penggunaan media pembelajaran dengan basis virtual reality dapat menghadirkan secara nyata objek cagar budaya di Pasuruan. Pembelajaran sejarah lokal menggunakan aplikasi virtual reality ini memberikan pemahaman yang lebih baik utamanya terkait cagar budaya di Pasuruan. Adanya virtual reality cagar budaya Pasuruan dapat membuat siswa dan guru tidak perlu datang langsung ke lokasi dan mempermudah proses pembelajaran lebih kontekstual.
\end{abstract}

Kata Kunci: Cagar Budaya; Pembelajaran Sejarah Lokal; Virtual reality.

HISTORIA: Jurnal Pendidik dan Peneliti Sejarah, p-issn:2620-4789 | e-issn:2615-7993 


\section{PENDAHULUAN}

Wilayah Indonesia memiliki cagar budaya baik yang sudah terekspos ke media maupun belum. Salah satu wilayah yang memiliki berbagai kekayaan cagar budaya adalah Pasuruan. Pasuruan memiliki banyak potensi ditemukannya cagar budaya mulai dari zaman kerajaan tradisional hingga masa kontemporer. Hal ini dapat dimanfaatkan sebagai materi sejarah lokal di jenjang sekolah menengah, Akan tetapi, kenyataan di lapangan berbeda, pembelajaran mengenai sejarah lokal khususnya cagar budaya Pasuruan utamanya yang terkait dengan kebudayaan sangat kurang. Hal ini disebabkan karena akses yang sulit serta biaya yang mahal menyebabkan guru tidak mengajak siswanya ke cagar budaya tersebut. Misalnya untuk melihat Candi Gununggangsir, pengunjung harus menempuh jarak yang cukup jauh dari pemberhentian angkutan umum.

Cagar budaya berfungsi untuk memperjelas identitas suatu bangsa karena berupa hasil-hasil budaya yang khas dan dimiliki bersama oleh suatu banga tersebut (Bahri, dkk: 2019). Pembelajaran tentang cagar budaya dapat mendukung adanya pembangunan pendidikan dan pariwisata budaya yang telah digalakkan oleh Kementerian Pendidikan beberapa tahun terakhir. Materi mengenai cagar budaya dapat dimasukkan kedalam pembelajaran sehingga siswa mengenal mencintai dan merasa memiliki peninggalan sejarah lokal di wilayahnya. Urgensi pembelajaran berbasis cagar budaya selain untuk meningkatkan pendidikan karakter juga diharapkan untuk meningkatkan kesadaran sejarah siswa. Kesadaran sejarah berguna untuk mengetahui fakta-fakta sejarah yang ada sekaligus untuk membentuk identitas suatu bangsa yang luhur dan disegani.

Pelestarian cagar budaya di wilayah Pasuruan juga mengalami beberapa kendala yang cukup rentan. Tidak adanya upaya pelestarian ini akan menimbulkan berbagai permasalahan lain seperti rusaknya bangunan, tindakan vandalisme hingga klaim dari individu atau kelompok yang tidak bertanggungjawab. Proses globalisasi dan modernisasi menjadi ancaman yang dapat menghambat pelestarian cagar budaya. Kurangnya wawasan masyarakat mengenai cara melestarikan suatu cagar budaya merupakan masalah utama dalam hal ini. Tanpa adanya wawasan yang memadai, maka masyarakat tidak akan dapat melakukan pelestarian cagar budaya. Alasan lain yang melatarbelakangi permasalahan ini yaitu Sumber Daya Manusia (SDM) yang belum memadai untuk pengelolaan cagar budaya. Kurangnya sumber daya ini merupakan dampak dari minimnya wawasan serta kesadaran masyarakat utamanya generasi muda untuk melestarikan cagar budaya.
Menurut Undang-Undang Republik Indonesia Nomor 11 Tahun 2010 mengenai cagar budaya, menyatakan bahwa cagar budaya adalah benda bangunan, struktur, siklus dan kawasan yang memiliki nilai penting bagi sejarah, ilmu pengetahuan, agama dan kebudayaan dalam kehidupan bermasyarakat, berbangsa atau bernegara. Cagar budaya merupakan bentuk dari hasil kebudayaan yang merupakan hasil interaksi antara manusia dengan lingkungannya. Kebudayaan dan hasilnya tidak dapat dipisahkan dari siklus kehidupan manusia.

Cagar budaya yang berada di wilayah Pasuruan pada beberapa kasus mengalami kondisi yang memprihatinkan. Misalnya pada situs Candi Belahan yang mengalami keausan pada patung Dewi Sri dan Dewi Laksmi. Bagian yang aus adalah pada payudara keduanya. Hal ini disebabkan karena banyak pengunjung dengan sengaja menyentuhnya untuk kepentingan kepercayaan. Selain itu, permasalahan juga terjadi di beberapa cagar budaya peninggalan masa kolonial yang beralih fungsi sebagai sekolah. Hal ini terjadi pada gedung Harmoni yang saat ini djadikan sebagai tempat proses belajar mengajar bagi siswa SMK Untung Surapati. Cagar budaya harus tetap terjaga dengan asri sehingga seharusnya tidak diperbolehkan untuk dipergunakan sebagai sekolah. Perubahan cagar budaya hanya boleh dilakukan dengan syarat-syarat tertentu.

Pendidikan karakter merupakan upaya yang dilakukan untuk menanamkan nilai luhur bangsa kepada generasi penerus sehingga memiliki karakter yang sesuai dengan kepribadian bangsa. Peran pendidikan karakter pada saat ini sangat dibutuhkan karena adanya kemajuan teknologi dan peradaban sehingga memungkinkan terjadinya pergeseran nilai budaya. Pendidikan karakter berguna untuk mencetak generasi penerus bangsa yang memiliki kualitas tinggi dan tetap menjaga nilai-nilai luhur bangsa. Hal ini selaras dengan Undang Undang Nomor 20 Tahun 2003 Tentang Sistem Pendidikan Nasional Pasal 3 yang berbunyi bahwa "Pendidikan Nasional berfungsi mengembangkan kemampuan dan membentuk watak serta peradaban bangsa yang bermartabat dalam rangka mencerdaskan kehidupan bangsa, bertujuan untuk berkembangnya potensi siswa agar menjadi manusia yang beriman dan bertakwa kepada Tuhan Yang Maha Esa, berakhlak mulia, sehat, berilmu, cakap, kreatif, mandiri dan menjadi warga negara yang demokratis serta bertanggungjawab". Nilai pendidikan karakter dapat diperoleh dari beragam sumber, salah satunya adalah dari cagar budaya. Kekayaan cagar budaya meninggalkan nilai-nilai pendidikan karakter yang berguna bagi kehidupan. 
Permasalahan-permasalahan di atas merupakan bentuk dari tantangan di era global dimana muncul kebudayaan baru yang diiringi dengan majunya Ilmu Pengetahuan dan Teknologi (IPTEK). Dua tantangan ini seakan memberikan peluang kepada generasi muda untuk bekerjasama dengan pelaku kebudayaan dalam menghasilkan suatu inovasi yang dapat memberikan kontribusi untuk kepentingan pemajuan kebudayaan. Munculnya berbagai pembaharuan dalam teknologi dibidang kebudayaan akan menyebabkan tersebarnya unsur-unsur kebudayaan asli Indonesia dan dapat digunakan untuk mengembankan pembelajaran sejarah lokal.

Perkembangan ilmu pengetahuan serta teknologi yang lebih maju memberikan dampak yang luar biasa dalam pendidikan di Indonesia. Salah satu bentuk perkembangannya adalah adanya pembelajaran digital yang diimplementasikan dalam berbagai matapelajaran termasuk sejarah. Berdasarkan riset ditemukan bahwa masyarakat Indonesia penggunaan smartphone dan internet mengalami kenaikan yang cukup signifikan, hal ini dibuktikkan dengan adanya penggunasalah satu situs media sosial hingga mencapai 63 juta serta adanya akses internet ke 34 situs dalam sehari (Sulistyowati \& Rachman, 2017). Hal ini dapat dimanfaatkan dalam pembelajaran sejarah utamanya dalam menghadirkan suatu situs sejarah secara nyata tanpa harus datang ke tempatnya. Guru dapat mengintegrasikan media pembelajaran virtual reality dalam pembelajaran kooperatif dengan memberikan siswa kesempatan untuk menguraikan dan menganalisis kondisi suatu cagar budaya. Hal ini juga menjadi solusi untuk meningkatkan pengetahun siswa mengenai cagar budaya Pasuruan dan berdasarkan angket terdapat 55\% kalangan siswa yang hanya pernah mendengar nama dari situs, serta $40 \%$ diantaranya pernah mengunjungi tanpa tahu arti sejarahnya. Oleh karena itu dibutuhkan suatu media virtual reality berbasis cagar budaya untuk menigkatkan wawasan sekaligus menjadi media pembelajaran pada matapelajaran sejarah.

Virtual reality merupakan sebuah teknologi yang dapat menghadirkan suatu objek menjadi nyata. Pada proses pembelajaran virtual reality dimanfaatkan sebagai media pembelajaran yang dapat menghadirkan suatu objek secara nyata tanpa harus mendatangkan objeknya. Dalam proses pembelajaran sejarah peranan virtual reality sangat penting sebagai media pembelajaran. Hal ini terkait dengan adanya kontekstualisasi materi dari abstrak menuju ke konkret. Sejarah identik dengan berbagai macam peninggalan budaya mengharuskan guru membahas serta memberikan contoh secara nyata. Namun akibat jarak yang jauh, biaya, dan waktu menyebabkan hal ini jarang dilaksanakan. Oleh karena itu virtual reality menjadi solusi atas dilema tersebut. Guru tidak perlu lagi membawa siswa datang ke tempat sejarah tetapi hanya perlu memberikan media pembelajaran berbasis virtual reality kepada siswa. Adanya hal ini maka pembelajaran sejarah dapat lebih hidup dan lebih menarik perhatian siswa.

Permasalahan ini memberikan suatu solusi atas pengetahuan dan pelestarian cagar budaya di Pasuruan berupa Perancangan Aplikasi Virtual reality. Adanya aplikasi ini diharapkan memberikan wawasan menjadi media pembelajaran di Pasuruan. Pada artikel ini akan dibahas mengenai konsep perancangan aplikasi virtual reality cagar budaya di Pasuruan. Kemudian efektivitas penggunaan aplikasi virtual reality cagar budaya di Pasuruan dalam kegiatan pembelajaraan sejarah lokal pada matapelajaran sejarah juga akan dibahas dalam artikel ini. Tujuan utama dari artikel ini adalah mendeskripsikan rancangan dari aplikasi virtual reality cagar budaya dan efektivitasnya dalam kegiatan pembelajaran di kelas.

Artikel ini bertujuan untuk memberikan suatu deskripsi dari adanya inovasi pengembangan media pembelajaran virtual reality cagar budaya Pasuruan. Media pembelajaran ini difokuskan untuk matapelajaran sejarah yang digunakan pada materi Indonesia masa hindu-buddha dan era kolonial. Hal ini dimaksudkan untuk memudahkan proses pembelajaran sejarah yang saat pembelajaran guru tidak dapat menghadirkan cagar budaya dan tidak dapat melakukan lawatan ke suatu situs sejarah. Adanya media pembelajaran ini dapat memudahkan guru untuk menghadirkan sekaligus menjelaskan suatu cagar budaya dengan adanya contoh asli tanpa harus datang langsung kesana.

Penggunaan virtual reality sering digunakan dalam pembelajaran sejarah di luar negeri. Dalam artikel yang berjudul "virtual worlds vs books and videos in history education" digambarkan mengenai pemanfaatan virtual reality dalam mengajarkan sejarah peradaban Mesopotamia. Adanya keterbatasan waktu, jarak, dan kondisi dalam merekontruksi atau pergi ke puingpuing peradaban Mesopotamia mengharuskan guru membuat suatu inovasi untuk menghadirkan suatu situs sejarah dalam kelas. Hal ini juga dilakukan pada artikel ini yaitu dengan membuat virtual reality mengenai Kota Uruk pada masa peradaban Mesopotamia. Media ini dimaksudkan untuk memudahkan guru dalam merekontruksikan serta mencontohkan dunia semasa Kota Uruk masih berjaya melalui dunia virtual (Ijaz et al., 2016). Tidak hanya terfokus pada situs Kota Uruk 


\section{Shela Dwi Utari, Maya Luthfia Agustin, Adam Maulana Dzikri, Lutfiah Ayundasari \\ Perancangan Aplikasi Virtual Reality Cagar Budaya untuk Pembelajaran Sejarah}

tetapi pada kehidupan sosial budaya masyarakatnya melalui kehadiran avatar manusia kuno yang disesuaikan dengan sejarahnya. Penggunaan media ini dilakukan dengan membentuk tiga kelompok yang diberikan kesempatan untuk mengamati dan mempelajari Kota Uruk melalui virtual reality, video serta melalui buku (Ijaz et al., 2016). Kelompok pertama akan mempelajari sistem Kota Uruk melalui buku, kelompok dua aan belajar materi tersebut dari video, dan kelompok terakhir akan mempelajarinya melalui virtual reality. Kemudian setelah pengamatan dan pembelajaran tersebut, maka tiap kelompok akan menyajikan hasil analisisnya dengan mempresentasikannya di kelas. Berdasarkan percobaan tersebut maka ditemukan bahwa kelompok virtual memiliki nilai yang lebih baik daripada kelompok lainnya, karena secara virtual turut dalam kehidupan di Kota Uruk.

Virtual reality merupakan alat yang valid untuk berinteraksi dengan model tiga dimensi dan memberikan akses budaya yang lebih mudah untuk masyarakat luas dengan mendokumentasikan, mencatat dan konservasi warisan budaya (Barsanti, 2015). Teknologi virtual reality terus berkembang sehingga dapat dijumpai berbagai jenis virtual reality seperti Entry-Level Mobile VR, Mobil Virtual reality, dan High-Level Virtual reality. Beragam jenis virtual reality tersebut dapat digunakan sesuai kebutuhan pengguna. Pemanfaatan teknologi virtual reality dalam pembelajaran memberikan kesempatan kepada guru dan siswa untuk melakukan pembelajaran sejarah tanpa harus melakukan karya wisata. Selain itu, pemanfaatan teknologi virtual reality dalam pembelajaran sejarah juga merupakan salah satu cara untuk menghubungkan pendidikan dengan perkembangan zaman yang ditandai dengan majunya teknologi. Pada era ini, siswa sangat akrab dengan teknologi sehingga media pembelajaran berbasis teknologi sangat dibutuhkan. Teknologi virtual reality mendukung efektivitas dan efisiensi dalam pembelajaran di kelas.

Pemanfaatan cagar budaya untuk pembelajaran telah diterapkan di berbagai belahan dunia. Salah satunya adalah pembelajaran mengenai rute kastil Arauce di Portugal yang dilakukan oleh Magro, Calvarho, dan Marcelino (2014). Pembelajaran tersebut memanfaatkan teknologi georeferensi historis yang ditampilkan dalam google earth untuk melihat rute kastil secara virtual. Hasil dari penelitian tersebut adalah siswa mengalami peningkatan pengetahuan dan nilai akan warisan kebudayaan sehingga dapat memiliki kesadaran sejarah dan menghormati warisan kebudayaan tersebut. Penelitian lain tentang pemanfaatan cagar budaya dalam pembelajaran dilakukan oleh Ma'tsaroh (2014) dengan mengembangkan media pembelajaran sejarah mengenai Candi Sari, Candi Ratu Bokodan Candi Sambisari untuk meningkatkan kesadaran sejarah siswa. Hasilnya adalah peningkatan kesadaran sejarah siswa yang telah diberikan pembelajaran sejarah berbasis cagar budaya.

Berdasarkan penelitian-penelitian diatas maka kajian dalam artikel ini berfokus pada pengembangan virtual reality terkait cagar budaya di Pasuruan. Virtual reality cagar budaya Pasuruan digunakan sebagai media pembelajaran dalam menunjang proses belajar siswa di kelas. Adanya aplikasi virtual reality ini dapat mempermudah proses pembelajaran dimana siswa dan guru tidak perlu datang langsung ke lokasi cagar budaya.

\section{METODE}

RAD (Rapid Application Development) merupakan suatu metode perancangan software yang menekankan pada daur pengembangan aplikasi yang singkat. RAD merupakan versi adaptasi cepat dari metode waterfall (Putri \& Effendi, 2018). Pengembangan aplikasi menggunakan metode ini relatif cepat pada waktu pengerjaannya. Pada metode ini terdapat beberapa tahap yaitu: Requirements Plannning (persiapan), pada tahap ini akan melakukan pengumpulan resources yang dibutuhkan saat pengembangan, pengidentifikasian tujuan aplikasi, dan penyelesaian masalah yang dari permintaan user atau dari studi kasus, studi kepustakaan. rapid application development (RAD), design and testing (mendesain aplikasi dan melakukan percobaan), pada tahap ini, dilakukan langsung oleh pemrogram dan penganalisa, dan implementation (tahap pelaksanaan). Berikut tahap-tahap dalam perancangan virtual reality Cagar Budaya.

\section{Requirements Plannning (persiapan)}

Pada tahap ini dilakukan pemilihan topik, pengidentifikasian masalah, penghimpunan data, dan perumusan solusi. Topik pada artikel ini adalah pembuatan media pembelajaran berbasis digital dan cagar budaya dalam proses belajar sejarah di sekolah. Kemudian dilakukanlah tahap pencarian dan identifikasi permasalahan melalui penyebaran angket terkait pembelajaran sejarah saat ini dan cagar budaya di wilayah Pasuruan. Penelitian ini menggunakan subjek penelitian berupa siswa SMA yang tersebar di wilayah Pasuruan. Berdasarkan penyebaran angket dan studi pustaka diperoleh bahwa kebanyakan siswa tidak tertarik dengan pembelajaran sejarah karena materinya tidak kontekstual dan bersifat abstrak. Selain itu, siswa tidak mengerti arti dari cagar budaya dan persebarannya di wilayah Pasuruan. Berdasarkan permasalahan ini 
maka dapat diberikan sebuah solusi dimana adanya pemanfaatan virtual reality dalam menghadirkan secara nyata cagar budaya di Pasuruan dalam pembelajaran sejarah. Hal ini terkait dengan kontekstualisasi materi dan untuk menghadirkan pembelajaran sejarah yang lebih konkret.

\section{Rapid Application Development (RAD) Design and Testing (mendesain aplikasi dan melakukan percobaan)}

Pada tahap ini dilakukan desain aplikasi virtual reality cagar budaya Pasuruan melalui blender, vuforia, dan unity 3D. Kemudian setelah desain selesai dilakukan build aplikasi untuk pembentukan prototype yang nantinya akan diuji kelayakannya melalui ahli media dan materi. Setelah dianggap layak maka dilakukan uji coba secara mikro kepada guru dan siswa SMA serta memberikan responnya melalui angket uji kelayakan. Kemudian setelah uji coba masukan yang didapat dari user disempurnakan dalam membuat aplikasi.

3. Implementation (tahap pelaksanaan)

Pada tahap pelaksanaan maka aplikasi virtual reality cagar budaya yang sudah ada akan disosialisasikan dan diterapkan di sekolah. Penerapan aplikasi ini diwujudkan melalui proses pembelajaran sejarah pada materi Indonesia masa hindu buddha dan kolonial. Kemudian ketika terdapat kekurangan atau masukan dari user maka aplikasi dapat disempurnakan dan diperbaiki secara berkala.

\section{PEMBAHASAN}

\section{Pemaknaan Cagar Budaya Pasuruan Sebagai Pendidikan Karakter}

Cagar budaya dalam pembelajaran sejarah erat kaitannya dalam penerapan kurikulum 2013, dimana seorang guru dituntut untuk mengajarkan nilainilai karakter dari matapelajaran. Karakter memiliki pengertian suatu sifat dan tabiat manusia yang dapat diobservasi setiap harinya (Yetri \& Firdaos, 2017). Tiap nilai-nilai karakter bangsa dianggap sebagai dasar dalam upaya pembangunan tabiat generasi muda yang sesuai dan dapat membangun negaranya. Oleh karena itu pemerintah gencar melakukan upaya penanaman karakter bangsa melalui pendidikan karakter. Tujuan dari pelaksanaan pendidikan karakter yaitu mendidik siswa untuk menjadi manusia Indonesia yang sempurna, bijaksana, dan bertanggung jawab dalam melakukan segala hal serta dapat memberikan pengaruh positif dilingkungan masyarakat (Yetri \& Firdaos, 2017).
Pendidikan karakter tidak berdiri sendiri sebagai suatu matapelajaran tertentu namun terintegrasi dengan pelajaran lain dan disesuaikan dengan ciri khasnya. Misalnya pada matapelajaran matematika dalam upaya penanaman nilai karakter bangsa pasti berbeda dengan pendidikan agama islam. Selain itu cara penanaman nilai karakter juga disesuaikan dengan proses pembelajaran gurunya. Dalam pembelajaran guru dapat menanamkan nilai karakter melalui media pembelajaran, penyampaian materi, ataupun pada saat outdoor learning. Pada pembelajaran sejarah, guru dapat mencotohkan dan menanamkan pendidikan karakter melalui cagar budaya yang penuh dengan nilai-nilai karakter bangsa.

Sejarah selalu erat dengan peristiwa masa lalu yang dipenuhi dengan nilai-nilai karakter bangsa dan membentuk suatu identitas. Peristiwa sejarah menjadi suatu momentum penting dalam perjalanan bangsa dan dapat membentuk generasi muda yang memiliki identitas nasional. Oleh karena itu pembelajaran sejarah menjadi salah satu matapelajaran penting dalam upaya penanaman dan pelaksanaan pendidikan karakter. Pendidikan karakter yang diajarkan dalam pembelajaran sejarah dapat diambil dari jalannya peristiwa sejarah ataupun hasil dari suatu kebudayaan. Misalnya suatu situs candi yang memiliki nilai-nilai sakral dalam aspek religi, memiliki nilai gotong royong dalam pembangunannya, dan mencerminkan nasionalisme karena berdiri diatas keberagaman bangsa. Hal ini dapat diajarkan agar siswa dapat mengambil contoh nyata tersebut dan menerapkannya dalam kehidupan sehari-hari.

Pendidikan karakter dalam konteks pembelajaran sejarah erat kaitannya dengan kesadaran sejarah. Manusia yang memiliki kesadaran sejarah akan menjadikannya lebih kritis dalam menghadapi permasalahan, memiliki wawasan yang luas, mempunyai rasa patriotisme dan nasionalisme yang tinggi, serta menjadi bijaksana dalam mengambil keputusan. Sejarah mengajarkan siswa untuk lebih bijaksana utamanya banyak peristiwa yang memberikan dampak luar biasa bagi kehidupan masa kini dan masa depan. Pembelajaran sejarah yang syarat akan makna nilai-nilai pendidikan karakter akan membentuk generasi yang tahu dan paham akan jati dirinya sebagai bangsa Indonesia. Peristiwa sejarah yang merupakan momentum penting dalam perjalanan bangsa Indonesia akan dijadikan sebagai pertimbangan agar menjadi warga negara yang baik, bermoral, dan bermartabat. Oleh karena itu sejarah sangat penting peranannya dalam menanamkan pendidikan karakter di sekolah. Berikut nilai-nilai pendidikan karakter yang terkandung pada Cagar Budaya yang terletak di Pasuruan 
Nilai Religius

Candi Jawi merupakan hasil kebudayaan yang memancarkan nilai religius didalamnya. Pendiri candi Jawi adalah Krtanagara yang beragama Buddha Tantrayana, namun karena alasan tertentu telah menghidupkan Konsep Syiwa-Buddha, yaitu suatu pandangan adanya persamaan hakikkat tertinggi dari Buddha, Syiwa, Wishnu dan lain lain dengan emanasinya (Sedyawati, 2013). Berdasarkan hal tersebut dapat disimpulkan bahwa Candi Jawi adalah candi yang bernafaskan agama sinkretisme Syiwa-Buddha. Candi Jawi juga merupakan tempat dilaksanakannya ritual atau upacara keagamaan masa itu. Selain Candi Jawi, terdapat Candi Gununggangsir dan Patirtaan Belahan yang mengandung nilai religius di dalamnya. Patirtan Belahan memiliki beberapa arca dewa agama Hindu seperti Dewa Wishnu dan Dewi Laksmi.

Berdasarkan bukti tersebut, nilai religius pada Cagar Budaya di Pasuruan yang dapat diteladani dalam kehidupan saat ini adalah keimanan terhadap Tuhan Yang Maha Esa dengan melakukan ajaran agama. Nilai lainnya yang dapat dipetik adalah nilai kerukunan antar umat beragama. Pengamalan nilai religius pada saat ini dapat dilakukan dengan meningkatkan rasa toleransi antar umat beragama sehingga kehidupan semakin damai dan sejahtera.

\section{Nilai Nasionalisme}

Nilai pendidikan karakter tidak terlepas dari nilai nasionalisme atau cinta tanah air. Benihbenih nasionalisme telah ada sejak masa kerajaan Singhasari. Hal itu dibuktikan dengan adanya Candi Jawi yang bernafaskan Syiwa Buddha. Berdasarkan Kitab Nagarakrtagama, pupuh 56, Raja Kertanagara menginginkan agar pemeluk agama Syiwa dan Buddha akan selalu beribadah bersama (Santiko, 2020). Keinginan Raja Kertanagara terwujud dan dibuktikan dengan kehidupan masyarakatnya yang rukun dan damai.

Nilai nasionalisme yang dapat dipetik dari sejarah Candi Jawi adalah harus adanya rasa persatuan diantara berbagai perbedaan. Perbedaan bukanlah penghalang, tetapi perbedaan dapat saling melengkapi. Pada saat ini, Indonesia memiliki penduduk yang terdiri dari berbagai macam suku bangsa. Maka dari itu, hendaknya generasi muda senantiasa meningkatkan toleransi dan memupuk rasa persatuan sehingga Indonesia mampu menjadi negara yang maju.

\section{Nilai Integritas}

Nilai integritas merupakan komitmen seseorang dalam perkataan dan perbuatan berdasarkan nilai kemanusiaan. Nilai integritas telah ada ketika Raja Kertanagara memimpin kerajaan Singhasari. Raja Kertanagara merupakan raja yang bijaksana, sehingga masyarakatnya dapat hidup dengan harmonis. Oleh karena itu, nilai integritas yang dapat diambil dari sejarah Candi Jawi adalah sikap tanggungjawab, kesetiaan dan komitmen terhadap negara. Sebagai warga negara yang baik, maka harus senantiasa menjalankan hak dan kewajibannya pada negara. Selain itu, setiap orang harus menghargai dan tidak merenggut hak orang lain.

\section{Cagar Budaya di Wilayah Pasuruan}

Pasuruan adalah wilayah yang terdiri dari satu kabupaten dan satu kota dan berada di Jawa Timur. Wilayah Pasuruan sudah dikenal strategis sejak zaman kerajaan tradisional. Hal ini ditandai dengan digunakannya Pasuruan sebagai pelabuhan transito untuk perdagangan. Pelabuhan-pelabuhan tersebut dilestarikan hingga zaman kolonial dimana Pasuruan selain menjadi tenpat transit juga berfungsi sebagai perkebunan tebu utama di Pulau Jawa.

Banyaknya cagar budaya yang berasal dari masa kerajaan tradisional hingga kolonial menjadi bukti bahwa Pasuruan pernah menjadi daerah yang ramai pada masanya. Seiring berjalannya waktu cagar budaya ini seolah dilupakan dan hilang ditelan pesatnya kemajuan zaman. Pada zaman penjajahan Jepang misalnya, pada cagar budaya Candi Gununggangsir banyak arca serta relief yang diambil untuk diperdagangkan dan dimanfaatkan sebagai dana perang (Ma’rufin \& Utari, 2018). Kemudian terdapat pula gedung-gedung era kolonial yang dialih fungsikan sebagai bangunan sekolah, dan milik pribadi. Selain itu banyak pula yang dirobohkan, dihancurkan, serta digantikan dengan bangunan yang baru.

Permasalahan diatas menjadi bahaya laten bagi pelestarian cagar budaya yang memiliki nilai historis yang tinggi. Beberapa cagar budaya yang berada di Pasuruan antara lain:

\section{Candi Gununggangsir}

Candi Gununggangsir merupakan peninggalan era kerajaan Mataram Jawa bagian Timur. Berdirinya candi ini dilatarbelakangi agama Hindu yang pada candi terdapat cerita Nyai Srigati sebagai implementasi berhasilnya pertanian pada daerah tersebut (Ma'rufin \& Utari, 2018). Candi merupakan bentuk respon manusia terhadap kepercayaan dan lingkungannya. Bentuk candi menyerupai punden berundak pada masa prasejarah dianggap replika Gunung Mahameru yang dianggap suci dalam kaum hindu. Candi ini terletak di Dusun Kebon Candi, Desa Gunung Gangsir, Kecamatan Beji,

HISTORIA: Jurnal Pendidik dan Peneliti Sejarah, p-issn:2620-4789 | e-issn:2615-7993 
Kabupaten Pasuruan. Letaknya yang dekat dengan pemukiman menyebabkan candi ini sering dikunjungi oleh beberapa wisatawan lokal dan siswa SD. Namun pengunjung tersebut pada umumnya hanya ingin mengetahui dan berfoto saja tanpa mengetahui esensi kesejarahan didalamnya. Sedangkan terdapat pula siswa SMA yang ingin melakukan study tour ke candi tersebut namun terkendala oleh akses dan transportasi.

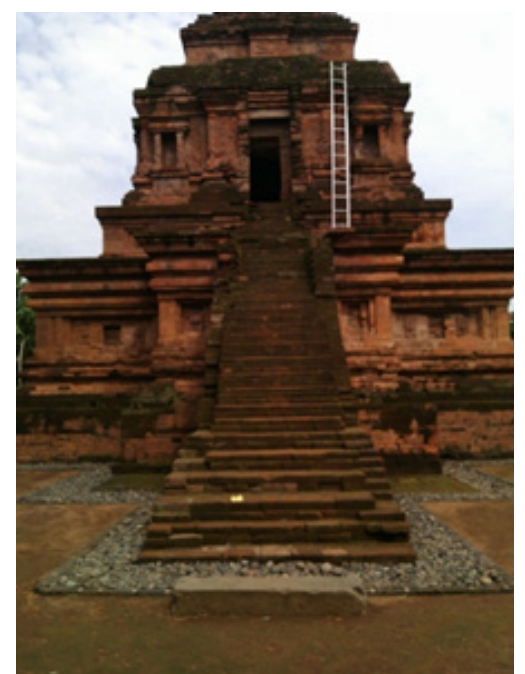

Gambar 1. Candi Gununggangsir tampak dari depan (Sumber: Dok Pribadi)

Candi Jawi

Candi ini merupakan peninggalan kerajaan Singhasari sebagai pendharmaan raja Kertanagara. Seperti candi Gununggangsir, Jawi juga berlatarbelakang agama sinkretisme Syiwa-Buddha yang berada di Desa Candiwates, Kecamatan Prigen, Kabupaten Pasuruan. Selain sebagai pendharmaan, candi ini juga digunakan sebagai tempat peribadatan kaum hindu. Selain itu, juga terdapat arca Siwa, Durga Mahesasuramardhini, Nandiswara, Ganesa, Brahma, dan Yoni. Kemudian terdapat pula candi perwara yang tinggal satu yaitu candi Bentar sebagai gerbang masuk pintu candi.

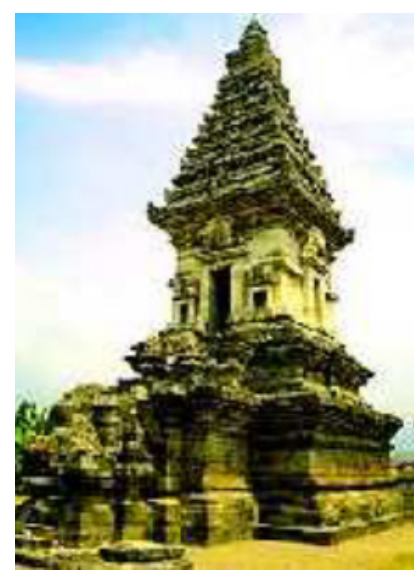

Gambar 2.2. Candi Jawi (Sumber: Paramadhyaksa, dkk, 2013)

\section{Pentirtaan Belahan}

Cagar budaya ini sebenarnya bukanlah sebuah candi yang umumnya disebut oleh masyarakat luas, namun berupa pentirtaan. Bangunan ini diperkirakan dibangun pada abad ke X-XI, walaupun hingga saat ini masih banyak diperdebatkan kepastiannya. Pentirtaan ini terletak di desa Desa Wonoayu, Gempol, Pasuruan (Rahadhian \& Wibawa, 2015). Pada bagian dinding pentirtaan ini terdapat tiga relung yang diisi masingmasing bagian tengah berupa arca dewa wisnu yang menaiki garuda dan dianggap sebagai pendharmaan raja Airlangga. Kemudian pada bagian kanan dan kiri adalah arca Dewi Sri dan Dewi Laksmi yang merupakan perwujudan kesuburan dan sering berada di berbagai pentirtaan di kerajaan Nusantara. Selain berupa pentirtaan terdapat pula paduraksa (gerbang) yang berupa sayap.

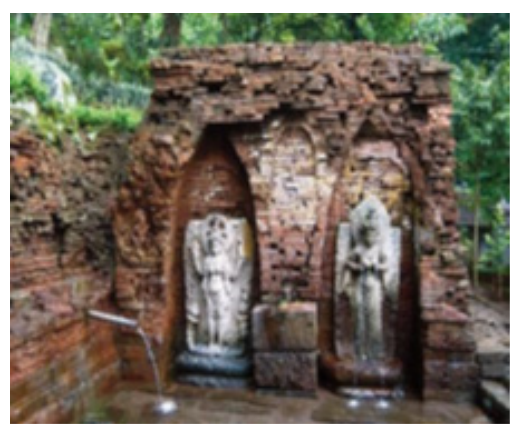

Gambar 2.3. Pentirtaan Belahan

(Sumber: Universitas Surabaya, 2013)

\section{Kelenteng Tjoe Tik Kiong}

Kelenteng ini merupakan peninggalan era kolonial yang dibangun pada 1740 dimana berada di kawasan pecinan. Hal ini menjadi bukti bahwa Pasuruan pernah menjadi pelabuhan yang disinggahi bangsa Cina dan mulai menetap. Klenteng ini terletak di Jalan Lombok No. 7 Kelurahan Trajeng, Kecamatan Gadingrejo, Kota Pasuruan (Yulis, 2018). Hingga saat ini eksistensi klenteng ini masih dapat dipertahankan. Namun permasalahan mengenai partisipasi aktif masyarakat utamanya generasi muda dalam melestarikan cagar budaya ini masih sangat diperlukan.

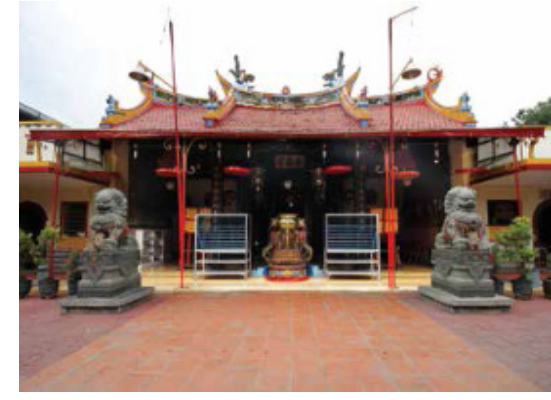

Gambar 2.4. Klenteng Tjoe Tik Kiong

(Sumber: Yulis, 2018)

HISTORIA: Jurnal Pendidik dan Peneliti Sejarah, p-issn:2620-4789 | e-issn:2615-7993 


\section{Shela Dwi Utari, Maya Luthfia Agustin, Adam Maulana Dzikri, Lutfiah Ayundasari \\ Perancangan Aplikasi Virtual Reality Cagar Budaya untuk Pembelajaran Sejarah}

\section{Gedung Wolu}

Gedung peninggalan kolonial ini berada di Kota Pasuruan dan dibangun pada sekitar abad ke 20. Pada awal penggunaan gedung ini digunakan sebagai kediaman pribadi Kapitein der Chineezen (Yulis, 2018). Namun seiring berjalannya waktu hingga saat ini gedung digunakan sebagai tempat pertemuan dan restoran. Nama gedung wolu berasal dari rumah yang dulunya memiliki arsitektur sama dan berjumlah delapan, sehingga dalam bahasa Jawa disebut dong wolu atau dalam bahasa Indonesia berarti gedung delapan (Yulis, 2018). Bangunan ini memiliki gaya Indische Empire serta dipengaruhi ragam hias arsitektur Cina.

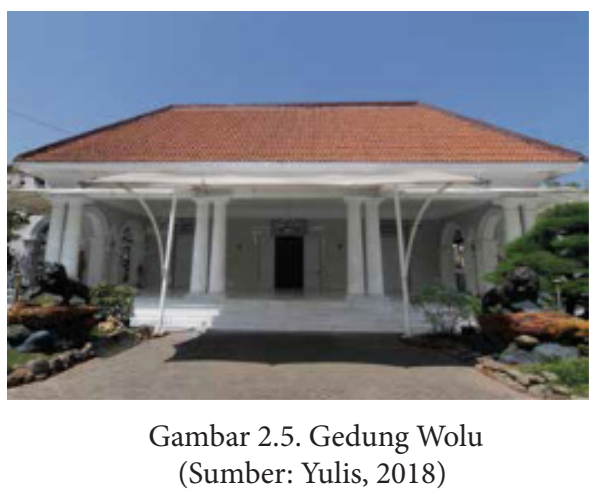

\section{Rumah Singa}

Rumah ini didirikan pada tahun 1825 dan kemudian dibeli oleh Tan Kong Seng pada 1840-an (Satrio, dkk, 2019). Rumah ini memiliki gaya Indische Empire yang berkembang di Perancis dan dipopulerkan oleh adik Napoleon Bonaparte yaitu Louis Napoleon. Perkembangan arsitektur ini di Nusantara ditunjang dengan adanya pemerintahan Herman William Deandels. Cagar budaya satu ini memiliki keunikan pada bagian halaman depan rumah terdapat patung singa. Patung singa pada halaman depan merupakan perwujudan dari kepercayaan Cina yang menganggapnya sebagai dewa pelindung.

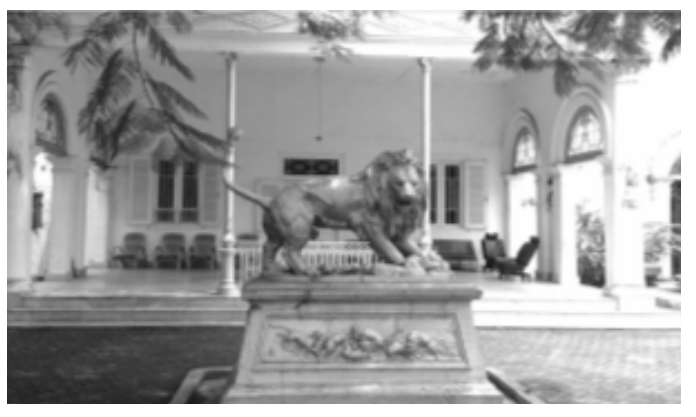

Gambar 2.6. Rumah Singa tampak depan

(Sumber: Yulis, 2018)

Beberapa cagar budaya diatas menjadi bukti bahwa Pasuruan memiliki potensi wisata kesejarahan yang menjanjikan. Namun hal ini menjadi suatu permasalahan ketika dalam pengelolaannya masih mengalami berbagai kendala seperti kurangnya wawasan dan kesadaran masyarakat utamanya generasi muda dalam ikut berpartisipasi aktif dalam pelestarian cagar budaya, serta kurangnya promosi untuk menarik wisatawan baik lokal maupun mancanegara.

Dalam hal ini dilakukan penyebaran angket terhadap siswa SMA di Pasuruan terkait cagar budaya. Berdasarkan hasil diatas diperoleh data bahwa siswa memiliki keterbatasan pengetahuan mengenai cagar budaya di Pasuruan. Siswa hanya pernah mendengar, melihat saat berada di institusi pendidikan maupun di media sosial. Terdapat pula yang mengujungi situs tersebut namun persentasenya hanya sebesar $40 \%$. Adanya kunjungan yang dilakukan siswa hanya terbatas pada wisata atau hanya ketika mendapat tugas dari sekolah. Hal ini cukup memprihatinkan karena dengan banyaknya cagar budaya yang tersebar di wilayah Kabupaten dan Kota Pasuruan hanya sebagian kecil saja yang memiliki wawasan mengenai hasil kebudayaan tersebut.

Ketidaktahuan siswa pada umumnya akan menimbulkan minimnya rasa kesadaran untuk melestarikan dan memanfaatkan cagar budaya tersebut. Oleh karena itu diperlukan suatu media untuk mengenalkan, memberikan pemahaman, yang nantinya akan berkelanjutan dengan peningkatan potensi wisata. Aplikasi virtual reality dapat digunakan sebagai bentuk pemecahan permasalahan diatas. Dengan memberikan gambaran secara nyata seolah individu turut aktif didalamnya, akan menimbulkan rasa keingintahuan yang diikuti dengan rasa memiliki yang diwujudkan melalui pelestarian dan meningkatkan pariwisata Pasuruan.

\section{Deskripsi Aplikasi Virtual reality Cagar Budaya Pasuruan}

Aplikasi virtual reality ini dibentuk dengan hasil analisis kebutuhan siswa Pasuruan yang mengalami krisis pariwisata berbasis cagar budaya di Pasuruan. Adanya aplikasi ini dapat memberikan realitas cagar budaya dengan memberikan keuntungan seperti dapat diketahui, dinikmati, dan dipelajari oleh siapa saja, kapan saja, dan dimana saja. Sistem kerja dari aplikasi virtual reality dengan nama VRGAR sendiri adalah visualisasi dari setiap cagar budaya yang ada di kota dan kabupaten Pasuruan. Pada aplikasi ini terdapat enam objek cagar budaya yang akan divisualisasikan yaitu rumah singa, gedung wolu, klenteng tjoe tik kiong, pentirtaan belahan, candi jawi, dan candi gununggangsir.

Sebelum penciptaan aplikasi virtual reality berbasis cagar budaya maka akan dilakukan tahap modeling

HISTORIA: Jurnal Pendidik dan Peneliti Sejarah, p-issn:2620-4789 | e-issn:2615-7993 
(visualisasi). Pada tahap ini, akan dilakukan visualisasi bentuk 3D agar budaya yang akan dimasukkan dalam aplikasi. Kemudian akan dibantu dengan efek animasi dan gyro untuk lebih memberikan kesan nyata. Tahap ini menggunakan aplikasi berbasis 3 dimensi seperti belnder. Seluruh bagian bangunan cagar budaya akan dibentuk 3 dimensi kemudian akan digabungkan dengan aplikasi unity dan vuforia. Setelah didapatkan visualisasi secara 3 dimensi dari cagar budaya maka dapat pula diberikan keterangan pendukung untuk memberikan kemudahan bagi siswa untuk menggunakannya.

Penggunaan aplikasi ini dikhususkan pada penyimpanan berbagai visualisasi virtual cagar budaya Pasuruan. User menggunakan virtual reality tool dan board untuk menikmati berbagai visualisasi yang disediakan. Kemudian terdapat penjelasan tiaptiap komponen cagar budaya secara lengkap untuk menunjang keberhasilan penyampaian informasi kepada siswa. Selain itu, adanya visualisasi secara 3 dimensi diharapkan dapat menghadirkan secara nyata bangunan cagar budaya ke hadapan siswa. Berikut ini adalah fiturfitur yang ada pada aplikasi VRGAR:

1. Halaman utama yang terdiri dari beberapa fitur berupa telusuri yang berfungsi untuk mencari cagar budaya yang berisi lokasi dan foto. Kemudian lestarikan berupa informasi mengenai cagar budaya di Pasuruan serta aspek-aspek yang dapat dilestarikan, Terakhir adalah konfigurasi yang berisi visualisasi 3 dimensinya diinginkan beserta dengan pembahasannya

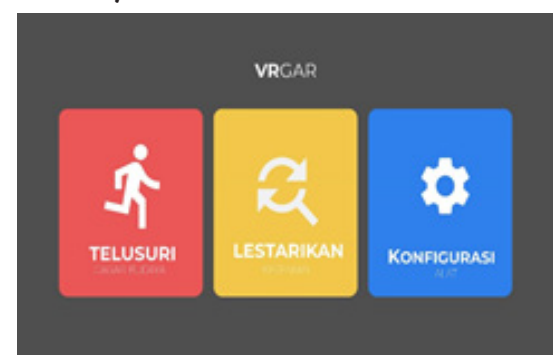

Gambar 2.7. Tampilan halaman utama aplikasi VRGAR (Sumber: Dok Pribadi)

2. Kemudian fitur telusuri yang terdiri dari berbagai macam cagar budaya di Pasuruan berupa peta, dan foto.

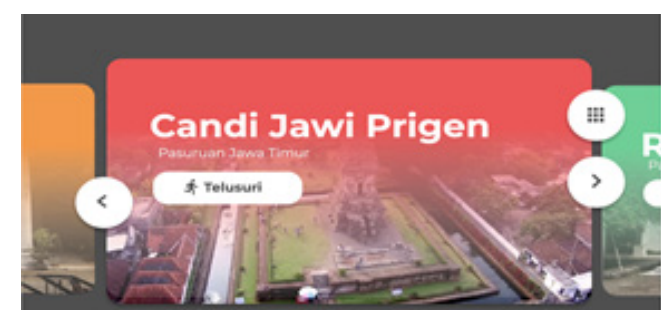

Gambar 2.8. Tampilan fitur telusuri aplikasi VRGAR (Sumber: Dok Pribadi)

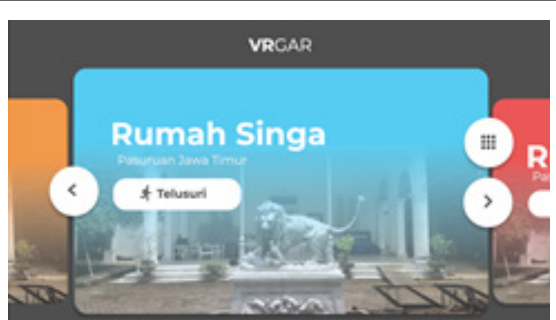

Gambar 2.9 Tampilan fitur telusuri aplikasi VRGAR

(Sumber: Dok Pribadi)

3. Konfigurasi berisi visualisasi cagar budaya Pasuruan dengan basis 3 dimensi dan terdapat pula pembehasan yang akan mempermudah user untuk memahami nilai-nilai kesejarahan bangunan tersebut.

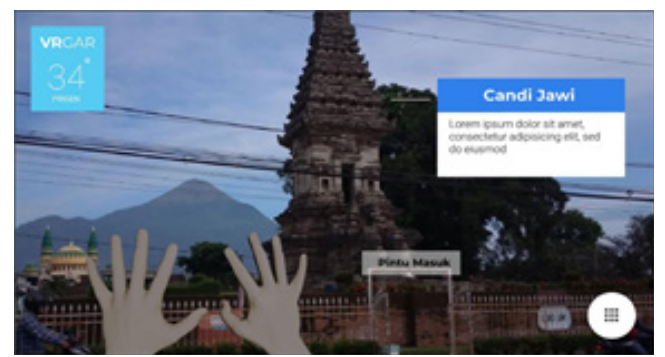

Gambar 2.10. Tampilan fitur konfigurasi aplikasi VRGAR (Sumber: Dok Pribadi)

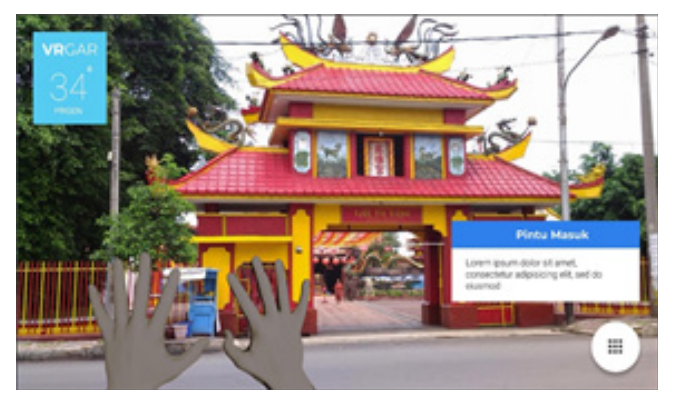

Gambar 2.11. Tampilan fitur konfigurasi aplikasi VRGAR (Sumber: Dok Pribadi)

Aplikasi VRGAR ditampilkan ketika pembelajaran sejarah terjadi di kelas. Pengaksesan aplikasi ini dapat menggunakan handphone android kategori 7.0 ke atas. Untuk terlihat lebih nyata maka siswa dapat menggunakan kacamata khusus virtual reality, sehingga objek 3 dimensi cagar budaya terlihat lebih realistis. Guru dapat menginstruksikan kepada siswa untuk mempelajari situs cagar budaya yang sesuai dengan materi dan mendeskripsikannya secara mandiri. Hal ini dapat membantu siswa untuk lebih memahami dan dapat menganalisis tiap-tiap ciri, fungsi, dan arti dari sebuah situs cagar budaya.

\section{Efektivitas Aplikasi Virtual reality Cagar Budaya dalam Pembelajaran Sejarah Lokal}

Sejarah lokal merupakan sejarah dari suatu tempat yang berfokus pada tempat, orang maupun

HISTORIA: Jurnal Pendidik dan Peneliti Sejarah, p-issn:2620-4789 | e-issn:2615-7993 
peristiwa yang terjadi pada tempat tersebut (Hariyono, 2017). Sejarah lokal merupakan refleksi dari jati diri suatu tempat yang penting dan dapat memberikan pengetahuan mengenai peristiwa lokal yang pernah terjadi dalam kurun waktu tertentu. Selain itu, sejarah lokal juga merupakan unit terkecil dari suatu peristiwa besar yang terjadi di masa lampau. Pembelajaran sejarah lokal adalah suatu upaya untuk menanamkan wawasan mengenai sejarah lokal bagi siswa. Upaya tersebut sangat penting untuk dilakukan agar siswa dapat mengenal dan memahami nilai-nilai sejarah yang ada disekitarnya. Wawasan mengenai sejarah lokal dapat mendorong siswa untuk memiliki kebanggaan atas sejarah lokal sehingga dapat menjaga, melestarikan dan memanfaatkan sejarah lokal dengan tepat. Pembelajaran sejarah lokal akan membantu siswa untuk menggali jati diri sejarah dan budaya yang dimilikinya.

Cagar Budaya merupakan situs yang memiliki keterkaitan dengan sejarah lokal. Situs bersejarah tersebut adalah tempat yang memiliki nilai sejarah dengan ciriciri antara lain yaitu terdapat benda peninggalan masa lampau, tempat kelahiran, kemangkatan atau makam tokoh penting, atau tempat dimana suatu peristiwa penting di masa lalu terjadi (Wibowo, 2016). UndangUndang Republik Indonesia Nomor 20 Tahun 2003 tentang Sistem Pendidikan Nasional menyatakan bahwa pendidikan nasional berfungsi untuk mengembangkan kemampuan dan membentuk watak serta peradaban bangsa yang bermartabat dalam rangka mencerdaskan kehidupan bangsa, bertujuan untuk berkembangnya potensi siswa agar menjadi manusia yang beriman dan bertakwa kepada Tuhan Yang Maha Esa, berakhlak mulia, sehat, berilmu, cakap, kreatif, mandiri, dan menjadi warga negara yang demokratis serta bertanggungjawab. Pembentukan watak serta peradaban bangsa yang bermartabat dapat diakukan dengan pembelajaran sejarah lokal. Pembelajaran sejarah lokal dapat menumbuhkan kesadaran sejarah dan meningkatkan nasionalisme yang berdasarkan pada nilai sosial budaya pada lokalitas tertentu. Hal itu membantu terbentuknya watak siswa dan peradaban bangsa yang bermartabat selaras dengan jati diri bangsa Indonesia.

Pembelajaran sejarah lokal dapat mendorong siswa untuk memahami karakter sosial budaya di lingkungannya. Akan tetapi, pembelajaran sejarah lokal memiliki berbagai hambatan antara lain terbatasnya sumber sejarah lokal, keterbatasan waktu dalam pembelajaran, dan media pembelajaran yang terbatas. Keterbatasan sumber sejarah lokal disebabkan karena sebagian besar sejarah lokal merupakan sejarah lisan dan benda, sedangkan sumber sejarah tulisan masih sedikit. Pembelajaran sejarah lokal mengenai cagar budaya sangat baik bila dilakukan dengan kunjungan ke cagar budaya terkait sehingga siswa dapat melihat secara langsung benda bersejarah yang ada dan dapat memiliki pemahaman yang mendalam mengenai tempat tersebut. Akan tetapi, waktu yang tersedia dalam pembelajaran sejarah lokal sangat terbatas sehingga seringkali hanya dilakukan di kelas.

Berdasarkan berbagai permasalahan di atas maka inovasi yang dapat diberikan berupa media pembelajaran Virtual reality Cagar Budaya. Virtual reality ini diharapkan dapat memberikan kontribusi dalam meningkatkan pemahaman siswa mengenai cagar budaya yang terdapat di Pasuruan. Virtual reality Cagar Budaya juga diharapkan dapat membantu pelestarian dan pemanfaatan Cagar Budaya Pasuruan secara efektif dan efisien.

Penggunaan aplikasi Virtual reality dalam pembelajaran sejarah lokal dapat dilakukan untuk meningkatkan pemahaman siswa mengenai benda cagar budaya yang ada di Pasuruan. Alat yang digunakan dalam pengoperasian aplikasi dapat dijumpai dan digunakan dengan mudah. Selain itu virtual reality juga bersifat interaktif dan efektif karena dapat menampilkan objek yang terlihat nyata serta dapat digunakan dimanapun dan kapanpun. Teknologi virtual reality juga dapat memberikan gambaran yang nyata mengenai objek-objek Cagar Budaya di Pasuruan. Aplikasi ini memungkinkan siswa untuk melihat dan mendengarkan program yang terdapat didalamnya sehingga siswa merasakan sensasi nyata. Objek tiga dimensi (3D) yang ditampilkan dengan detail sehingga dapat menambah wawasan siswa mengenai berbagai objek kebudayaan di Pasuruan.

Kemudian pembelajaran dengan materi cagar budaya Pasuruan juga akan menjadi interaktif jika guru dapat mengombinasikan antara virtual reality dengan berbagai model pembelajaran inovatif. Hal ini dimaksudkan agar pembelajaran sejarah yang dianggap membosankan dapat menjadi menyenangkan. Adanya kehadiran objek cagar budaya secara langsung tanpa harus datang ke tempatnya akan memberikan efisiensi waktu, dan materi. Guru dapat menjelaskan aspek-aspek kesejarahan suatu cagar budaya dengan objek nyata, sehingga siswa tidak hanya mendengarkan materi tetapi juga dapat berhadapan langsung dengan cagar budaya tersebut.

Penggunaan virtual reality pada pembelajaran sejarah lokal akan memberikan dampak yang lebih baik daripada menggunakan media lain seperti powerpoint, video, dan lain sebagainya. Hal ini disebabkan karena adanya kehadiran objek berbasis konkret dan tidak lagi abstrak. Pembelajaran sejarah lokal utamanya mengenai 
cagar budaya di Pasuruan mengharuskan guru untuk memberikan gambaran secara konkret mengenai bentuk, fungsi, serta sejarahnya. Namun, dalam pembelajaran tidak mungkin untuk menghadirkannya secara bersamaan dalam waktu yang singkat. Hal ini akan memakan waktu, tenaga, serta materi yang tidak sedikit sebagai akibat jarak antara satu objek dengan objek lain lumayan jauh. Selain itu, adanya spesialisasi tiaptiap cagar budaya yang memiliki periodesasi berbeda menyebabkan efektivitas pembelajaran sulit dicapai.

Virtual reality cagar budaya Pasuruan memberikan suatu solusi atas permasalahan diatas. Cagar budaya di Pasuruan dapat disatukan dalam satu aplikasi yang menghadirkan objek sesuai dengan periodesasi. Guru tidak perlu membawa siswa datang ke tempat objek berada, namun hanya perlu memberikan aplikasi pada siswa dan menjelaskannya. Hal ini dapat menunjang kebutuhan siswa yang dimana guru tidak hanya menjelaskan secara abstrak saja namun juga menghadirkan kenyataan objek didalam kelas.

Adanya visualisasi 3 dimensi suatu objek cagar budaya dapat memudahkan siswa untuk memahami materi sejarah lokal di Pasuruan. Misalnya materi mengenai situs candi Jawi, guru akan menjelaskan mengenai kerajaan Singhasari, fungsi candi Jawi, dan struktur candi. Selain mendengarkan penjelasan guru, siswa juga dapat mengamati serta memahami tiaptiap penjelasan dengan memerhatikan candi secara 3 dimensi. Adanya pengalaman secara konkret dapat lebih mengena dan akan diingat lebih lama oleh siswa. Hal ini dapat dijadikan sebagai suatu dorongan agar siswa dapat mengulang kembali materi yang telah disampaikan dengan baik.

\section{Penerapan Aplikasi Virtual Reality Cagar Budaya Pasuruan dalam Pembelajaran Sejarah Lokal}

Virtual reality merupakan teknologi yang memungkinkan penggunanya untuk mendapatkan gambaran nyata terhadap suatu benda tanpa melibatkan benda fisiknya. Teknologi ini dapat digunakan dalam berbagai bidang, salah satunya dalam bidang pendidikan. Rata-rata manusia hanya mampu mengingat 20\% informasi yang didengar, sedangkan 30\% mengingat apa yang dilihat, namun hampir $90 \%$ orang mampu mengingat informasi berdasarkan apa yang dialami (Sari \& Priatna, 2020). Berdasarkan fakta tersebut, teknologi Virtual reality dapat membantu siswa dalam mengingat informasi lebih baik.

Virtual reality Cagar Budaya dapat diterapkan dalam matapelajaran Sejarah di Sekolah Menengah Atas. Pembelajaran menggunakan virtual reality Cagar Budaya memungkinkan siswa untuk mengamati cagar budaya dengan lebih mudah dan efisien. Virtual reality Cagar Budaya juga memberikan kesempatan bagi siswa untuk menelusuri lebih dari satu cagar budaya yang ada di Pasuruan. Pembelajaran dengan media virtual reality juga dapat dikombinasikan dengan model-model pembelajaran interaktif sehingga siswa selain mendapatkan visualisasi yang baik, juga dapat menangkap nilai-nilai kebudayaan yang terkandung didalamnya. Penggunaan virtual reality Cagar Budaya didalam kelas juga diharapkan dapat meningkatkan keterampilan siswa dalam memahami perkembangan teknologi. Siswa juga dapat didorong untuk berpikir kritis dan kreatif. Hal tersebut akan meningkatkan keterampilan siswa untuk menghadapi era ini.

Pada penggunaan media virtual reality cagar budaya Pasuruan dalam pembelajaran sejarah dapat diintegrasikan dengan model pembelajaran kooperatif dengan materi Indonesia masa hindu-buddha pada kelas XI dan materi Indonesia masa kolonial pada kelas XI. Pengunaan media ini diterapkan pada model pembelajaran kooperatif tipe jigsaw. Dimana siswa dibagi dalam empat sampai lima kelompok, dan tiap anggota akan diberikan tugas berbeda untuk mengamati suatu situs sejarah. Anggota kelompok yang berbeda dengan tugas yang sama akan dikelompokkan lagi menjadi satu hingga dapat mendalami materi dari media yang disediakan. Kemudian setelah anggota ini memahami materinya, maka akan kembali ke kelompok asal dan menerangkannya pada teman-temannya. Setelah diberikan waktu agar para anggota dapat menerangkan dan memahami materi maka tiap kelompok menunjuk satu anggota untuk mempersentasikannya di depan kelas. Selain itu untuk evaluasi maka tiap kelompok akan menyusun laporan esai mengenai cagar budaya di Pasuruan yang telah dipelajari.

\section{SIMPULAN}

Pembelajaran sejarah lokal merupakan suatu pengenalan potensi kesejarahan dan lokalitas masyarakat di daerah sekitar sekolah tersebut. Hal ini diharapkan dapat memberikan kesadaran sejarah di tingkat institusi pendidikan. Pasuruan merupakan wilayah yang memiliki potensi sejarah lokal yang luar biasa, namun tidak diimbangi dengan adanya upaya pengenalan dalam aktivitas pembelajaran. Akibatnya, siswa banyak yang memiliki rasa ketidaktahuan dan kurang memiliki kesadaran sejarah untuk melestarikan cagar budaya tersebut. Oleh karena itu, guru perlu menghadirkan cagar budaya Pasuruan tersebut melalui pembelajaran sejarah lokal berbasis teknologi masa kini. Teknologi yang dimaksudkan adalah virtual reality, hal ini akan mempermudah guru dalam menghadirkan 
bangunan cagar budaya tanpa harus datang ke lokasi. Hasil dari pembelajaran ini diharapkan dapat memupuk kesadaran sejarah akan lokalitas di daerahnya, serta dapat melestarikan cagar budaya di wilayahnya.

\section{REFERENSI}

Bahri, S., dkk. (2019). Upaya pelestarian cagar budaya hollandsch inlandsche school (HIS) pertama di pontianak. GERVASI: Jurnal Pengabdian kepada Masyarakat, 3(1), 146-157.

Barsanti, S. G., Caruso, G., Micoli, L. L., Covarrubias Rodriguez, M., \& Guidi, G. (2015). 3D visualization of cultural heritage artefacts with virtual reality devices. In 25th International CIPA Symposium 2015 (Vol. 40, No. 5W7, pp. 165-172). Copernicus Gesellschaft mbH.

Hariyono. (2017). Sejarah lokal: mengenal yang dekat, memperluas wawasan, dalam Jurnal Sejarah dan Budaya, 11(2), 160-166.

Ijaz, K., Bogdanovych, A., \& Trescak, T. (2016). Virtual worlds vs books and videos in history education. Interactive Learning Environments, 25(7), 904-929.

Ma'rufin, Akhmad Fajar, \& Utari, Shela Dwi. (2018). Pemanfaatan candi gunung gangsir: upaya menumbuhkan kesadaran sejarah siswa SMAN 1 Purwosari Melalui Metode Outdoor Learning. Jurnal Pangadereng, 4(1), 169-179.

Ma’tsaroh, Z. H. (2014). Pengembangan media pembelajaran sejarah berbasis audio visual candi sari, candi ratu boko dan candi sambisari untuk meningkatkan rasa kesadaran sejarah siswa kelas xi ips di sman 1 prambanan sleman yogyakarta. Jurnal Pendidikan dan Sejarah, 12(1), 79-88.

Magro,G., Calvarho, R. D., \& Marcelino, M. J. (2014). Improving historylearning through cultural heritage, local history and technology. Paper presented at the meeting 10th International Conference Mobile Learning 2014. Madrid, Spain.

Paramadhyaksa, I Nyoman, dkk. (2013). Kajian komprehensif tentang makna filosofis arsitektur candi jawa. Laporan Penelitian. Bali: Universitas Udayana.

Putri, M. P., \& Effendi, H. (2018). Implementasi metode rapid application development pada website service guide "waterfall tour south sumatera. Jurnal SISFOKO, 7(3), 130-136.
Rahadhian, \& Wibawa, Fery. (2015). Kajian arsitektur percandian pertitaan di jawa (identifikasi). Research Report-Engineering Science, 1(1).

Santiko, H. (2020). Kehidupan beragama rajakertanagara. Kalpataru, Majalah Arkeologi, 29(1), 29-38.

Sari, R. M. M., \& Priatna, N. (2020). Model-model pembelajaran di era revolusi industri: e-learning, m-learning, ar-Learning, dan vr-Learning. Jurnal Biormatika, 6(1), 107-115.

Satrio, Evelyn Giovani, dkk. (2019). Perancangan buku esai foto bangunan heritage di kota pasuruan. Jurnal DKV Adiwarna, 1(14), 1-9.

Sedyawati, E., dkk. (2013). Candi indonesia seri jawa. jakarta: direktorat cagar budaya dan permuseuman, Direktorat Jenderal Kebudayaan, Kementerian Pendidikan dan Kebudayaan.

Sulistyowati, \& Rachman, A. (2017). Pemanfaatan teknologi $3 \mathrm{~d}$ virtual reality pada pembelajaran matematika tingkat sekolah dasar. Jurnal Ilmiah NERO, 3(1), 37-43.

Undang-Undang Republik Indonesia Nomor 11 Tahun 2010 Tentang Cagar Budaya. Jakarta: Balai Pelestarian Cagar Budaya.

Undang-Undang Republik Indonesia Nomor 20 Tahun 2003 tentang Sistem Pendidikan Nasional. 2016. Sistem Pendidikan Nasional. Bandung: Citra Umbara.

Universitas Surabaya, Tim Ekspedisi Penanggungan. (2013). Mengenal situs purbakala di gunung penanggungan. Surabaya. UBAYA Press.

Wibowo, A. M. (2016). Pengembangan model pembelajatan sejarah lokal di sma kota madiun. Jurnal Agastya, 6(1), 46-57.

Yetri, \& Firdaos, R. (2017). Penguatan pendidikan karakter berbasis masyarakat pada sekolah menengah pertama negeri (smpn) di kabupaten tulang bawang provinsi lampung. Al-Tadzkiyyah Jurnal Pendidikan Islam, 8(2), 267-279.

Yulis, C. (2018). Dokumentasi kota pasuruan: Eksotika bangunan bersejarah. Yogyakarta: Ciptamedia. 